Потьомкін Л. М., Д.е.н., професор

Дишкантюк О. В., к.т.н., доцент

Жосан В. Д., студент

Міжнародний гуманітарний університет

м. Одеса, Украӥна

DOI: https://doi.org/10.30525/978-9934-26-028-5-12

\title{
АНАЛІЗ ФАКТОРІВ ЗОВНІШНЬОГО СЕРЕДОВИЩА НА РОЗВИТОК РЕСТОРАННОГО ГОСПОДАРСТВА ОДЕЩИНИ В АСПЕКТІ ГАСТРОНОМІЧНОГО ТУРИЗМУ
}

Гастрономічний туризм, який останнім часом набуває все більше популярності у всьому світі [1], є перспективним видом туризму для розвитку в Одеському регіоні. Адже для цього є всі передумови. Гастрономічний туризм має низку переваг, зокрема він не носить сезонного характеру, що надзвичайно актуально для Одещини, як курортного регіону. Крім того, на етапі переходу до економіки вражень, гастрономічний туризм має суттєву перевагу в тому, що задіює всі п'ять органів чуттів людини, i відповідно, забезпечує яскраві враження. Будучи частиною національної культури, кухня приваблює як закордонних туристів, так і місцевих [2]. Об'єктами гастрономічного туризму є: країни з просунутою національною кухнею; регіони 3 відомою в світі локальною кухнею; знамениті ресторани 3 відзнаками; підприємства 3 виробництва харчових продуктів; кулінарні школи; локальні харчові системи, гастрономічні заходи (фестивалі, ярмарки, виставки, майстер-класи) [3].

В Одеському регіоні проводиться багато гастрономічних івентів, зокрема гастрономічних фестивалів. Разом з тим, на нашу думку, є ще нереалізований потенціал закладів ресторанного господарства, яке $є$ важливою складовою розвитку гастрономічного туризму, відіграючи велику роль у формуванні туристичного іміджу регіону. В аспекті гастрономічного туризму інтерес представляють заклади етнічної спрямованості. Аналіз закладів етнічної кухні Одеси підкреслює різноманіття культур 
регіону, що проявляється у місцевій кухні. Незважаючи на те, що протягом останнього періоду число закладів ресторанного господарства, які пропонують місцеву кухню в Одесі, зросло, ніша концептуальних закладів залишається незаповненою [4].

В даній роботі проведено аналіз факторів зовнішнього макросередовища концептуальних ресторанів місцевої кухні, як об'єктів гастрономічного туризму. Для оцінки конкурентного середовища ресторану використали метод STEP-аналізу.

Політико-правові фактори (P)

Позитивні:

- прийняття державної та регіональної стратегії та програми розвитку туризму;

- удосконалення транспортної інфраструктури (будівництво доріг Одеса-Рені, відновлення автошляху Білолісся-ПриморськеРосійка), що суттєво полегшує впровадження гастрономічних турів;

- удосконалення законодавства в сфері регулювання діяльності закладів ресторанного господарства (Закон «Про якість та безпеку харчових продуктів»);

- реформування законодавства в сфері надання послуг.

Негативні:

- посилення державного регулювання діяльності організацій ресторанного та готельного господарства у зв’язку з пандемією;

- політична нестабільність;

- нестабільність правового середовища;

- відсутність підтримки малого бізнесу з боку держави.

Економічні фактори (E)

Позитивні:

- добре розвинена інфраструктура;

- наявність великого числа виноробних підприємств, що дає змогу проектувати «дороги вина та смаку»;

- наявність концептуальних ресторанів місцевої кухні, гідних до включення до гастрономічних турів;

- наявність місцевих фермерських господарств, що виробляють місцеву сировину та продукцію високої якості. 


\section{Негативні:}

- недостатня кількість ресторанів місцевої кухні;

- рівень інфляції в країні;

- низький платоспроможний попит місцевого населення;

- недостатній рівень інвестицій в сферу гостинності;

- високі ставки банківських кредитів;

- високі орендні ставки;

- розвиток іноземних франчайзингових мереж;

- здорожчання енергоносіїв;

- дефіцит кадрів;

- відсутність бренду Одеси, як гастрономічного міста;

- недостатність маркетингових заходів 3 просування гастрономічного бренду Одеси.

Сочіально-культурні фактори $(S)$

Позитивні:

- зростання популярності гастрономічного туризму;

- мультикультурність регіону та розмаїття національних кухонь;

- феномен «одеська кухня»;

- зміна в базових цінностях населення;

- багата культурна та історична спадщина Одеси, що дає підгрунтя для створення тематичних закладів ресторанного господарства;

- проведення в регіоні великого числа різноманітних гастрономічних івентів, в тому числі фестивалів.

Негативні:

- зниження туристичних потоків внаслідок карантинних обмежень, пов'язаних з пандемією;

- зміна структури доходів і витрат населення;

- особливості «культури відвідування ресторанів» місцевого населення, що зумовлене спадком радянської системи;

- недостатньо розвинена «культура пиття» місцевого населення. Люди недооцінюють вітчизняні вина, що сповільнює їх внесення в винні карти ресторанів. 


\section{Технологічні фактори $(T)$}

Позитивні:

- широке впровадження в діяльність ресторанів інформаційних технологій;

- впровадження сучасного обладнання та технологій виробництва кулінарної продукції;

- впровадження сучасних технологій обслуговування.

Негативні:

- висока вартість професійного обладнання та обмеженість його виробництва в Україні;

- впровадження певних технологій призводить до втрати автентичності страви.

На основі проведеного аналізу, можливо зробити висновок про необхідність здійснення низки заходів щодо забезпечення розвитку концептуальних ресторанів місцевої кухні 3 метою включення їх до гастрономічних турів. Серед них - підтримка малого бізнесу з боку держави, необхідність створення гастрономічного бренду Одеси, здійснення комплексних маркетингових заходів щодо просування гастрономічного бренду Одеси, просвітницька робота щодо популяризації продукції місцевих виробників, підготовка професійних кадрів 3 гастрономічного туризму, розробка «доріг вина та смаку».

\section{Лiтература:}

1. Винний та гастрономічний туризм: глобальні тренди та локальні практики: монографія / за наук.ред. Д.І.Басюк. Вінниця : ПП «ТД «Едельвейс і К», 2017. 316 c.

2. Пахомов Ю.М. Система цінностей як фактор конкурентоспроможності країн у глобальному світі. Економіка ринкових відносин. 2008. № 1(1). С. 38-45.

3. Дишкантюк О. Гастрономія як важливий елемент розвитку індустрії гостинності / О. Дишкантюк, Д. Харенко, С. Саламатіна, Л. Івичук, В. Бородіна, К. Власюк. Економічна та продовольча безпека Украӥни. 2017. Вип. 3-4. С. 60-73.

4. Дишкантюк О., Харенко Д., Івичук Л. Потенціал ресторанного господарства Одещини в розвитку гастрономічного туризму. Економіка харчової промисловості. 2018. № 2(10). С. 32-37. 